\title{
Language Maintenance In New Millenium: A Case Of Javanese-Batak Toba Families
}

\author{
Vivi Novalia sitinjak ${ }^{1 *}$, Anna Tambunan ${ }^{2}$, Nurlaidy Simamora ${ }^{1}$, Pahotan Sinaga $^{1}$ \\ \{0112128701@methodist.ac.id* \} \\ ${ }^{1}$ Universitas Methodist Indonesia, Medan, Indonesia \\ ${ }^{2}$ Universitas Negeri Medan, Medan, Indonesia
}

\begin{abstract}
Medan is the biggest city in North Sumatera. In Medan, there are so many vernacular languages. Vernacular language is a symbol of ethnic identity. Maintaining vernacular language means maintaining identity. This study focuses on the dominant factor and the ways in vernacular language maintenance in Javanese-Batak families in Medan, Indonesia. There are four couples as subjects. This study applies qualitative research, especially case study. Data are taken from interview and observation. The technique of data analysis uses Miles and Huberman model which is divided into four steps; data collection, data reduction, data display, and conclusion drawing and verification. The findings of the data are 1) Attitude and parents' role at home are the dominant factor from three factors which influence the vernacular language maintenance in Javanese-Batak families. 2) Language maintenance can be done through three ways, they are: language choice at home, bringing children toethnic church, and hearing traditional songs.
\end{abstract}

Keywords: Language, Maintenance, Javanese-Batak, Families.

\section{Introduction}

Language as a mean of communication. it is done by people by arranging words to be sentences in order to construct meaning and make others people understand what speakers talk. The existence of language represents the temple of speakers' soul which relates to the interaction among tribes, ethnic groups, and religions (Holmes, 2013).

Language is one of ethnic identity symbols. It will be lost without maintenance. It is a must to maintain the language (Holmes, 2013). Language maintenance is an effort to keep the consistence of the language by using the language continually (Pauwels, 2005) (Hoffmann, 1996). So many vernacular languages in Indonesia, it causes the competition among languages. As a fact, Lengilu language in East Borneo is only spoken by 4 people. The competition among languages effects language shift. Language shift is the change of language in use dominantly. It works to language loss (Weinreich, 1979).

Maintaining vernacular language in inter-ethnic families is questioned. Communication between people from different ethnics sends and receives the message across language and culture. Verification of ethnic diversity as the identity from its ethnic is the objective of interethnic communication (Kim, 1995). The problem occurs because of the misconception of patriarch. Father as head of household has power in the family and it causes father's language must be maintained in family domain by shelving mother's language.

The aims of this study attempted to observe the dominant factor of vernacular language maintenance in Javanese-Batak Toba families in Medan and to investigate the process of language maintenance in Javanese-Batak Toba families in Medan. 


\section{Method Of Research}

This study was done by applying qualitative research especially case study. The instrument of data collection was mobile phone which was used to record the observation and the interview. The data were the recording of the observation and in-depth interview. The Data from observation and interview were transcribed. The subjects were 4 families who live in Medan, are able to speak their own vernacular languages, are Christian. The data analysis was done by applying Miles and Huberman technique which consisted of data collection, data reduction, data display, and conclusion drawing and verification (Miles \& Huberman, n.d.)

\section{Result}

\subsection{Factor of Language Maintenance}

\subsubsection{Attitude}

All parents have attitude toward their vernacular languages, especially Bataknese. Batak people have positive attitude to keep their symbol of identity alive. Batak People give surname for Javanese people who want to marry to Batak people. Javanese people who have surname attach to social ethnic groups and speak Batak Toba language when they meet Batak Toba People.

\section{Data 1}

Interviewer : Biasanya pakai bahasa apa di rumah? (What kind of language do you speak at home?

Parent : Bahasa Batak sama bahasa Indonesia (Batak language and Indonesian)

Interviewer : Kenapa pakai bahasa batak?

(why do you speak Batak language?)

Parent : Namanya orang Batak, ya pakai bahasa batak lah.

(Batak people speak Batak language)

The data 1 shows that Attitude motives the speakers to speak Batak Toba language as seen in "Namanya orang Batak ya pakai bahasa Batak (Batak people speak Batak)." Giving surname improve their prestige to be Batak. Being Batak is not only about culture but also language. Surname as the identity force them to speak Batak Language.

\subsubsection{Parents' Role at Home}

Parents' role is one of language maintenance factors applied by all parents. In Batak Tribe, Father as a head of household has an important role to choose the language used in family domain. There are two languages used; Indonesian and Batak Toba. Parents do codemixing in doing communication to their children.

\section{Data 2}

Interviewer: Kenapa pakai bahasa batak?

(why do you speak Batak?)

Parent : Namanya orang Batak, ya pakai bahasa batak lah. (Batak people speak Batak language)

Interviewer: Maksudny? (What do you mean?)

Parent : Yah, dikasih marga, sudah bagian dari batak, pakai bahasa batak lah kadangkadang sama mereka, di sini juga rata-rata orang batak. (Yeah, I have been 
given surname, already being part of Batak Toba tribe, sometimes, I speak Batak Toba to them, Most of people here are Batak).

The data indicates that Parents' role at home influences children acquisition. Children are forced to adopt Batak Toba language as stated "Pakai bahasa Batak lah kadang-kadang sama mereka (Sometimes, I speak Batak Toba to them)." Father has a positive attitude to maintain Batak language even he is not Batak naturally. It is also as the impact of Father's surname.

\subsubsection{Religion}

Bringing children to ethnic church is done by two parents to keep their children attitude to Batak Toba language alive. Reading holy bible in Batak Toba language and singing songs in Batak Toba language force children to understand Batak Toba language.

\section{Data 3}

Interviewer: Maksudny? (What do you mean?)

Parent $\quad$ : Yah, dikasih marga, sudah bagian dari batak, pakai bahasa batak lah kadangkadang sama mereka, di sini juga rata-rata orang batak. (Yeah, I have been given surname, already being part of Batak Toba tribe, sometimes, I speak Batak Toba to them, Most of people here are Batak).

Interviewer: selain itu ada hal lain? (is there any other factor ?)

Parent : apa ya, gereja kali ya, kan di sana pakai bahasa batak. (what, maybe church, we speak Batak Toba language there.)

This data is contradicted to two parents as display by data 4, Parents do not bring their children to ethnic church fellowship.

\section{Data 4}

Interviewer : Apakah Bapak dan ibu beribadah di gereja suku? (Do you join ethnic church fellowship?)

Parents : $\mathrm{Ga}(\mathrm{No})$

Bringing children to ethnic church forces children to be familiar to Batak Toba language. Parents who bring their children to ethnic church Force their children to be at Batak Toba Language environment.

It concludes that from four families, there are two families influenced by religion factor to maintain Batak Toba language.

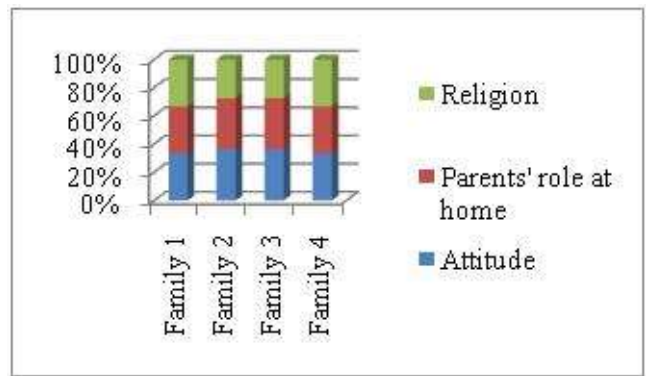

Fig. 1. Language Maintenance's Factors.

Figure 1 represents Religion factors contributed less than others subjects in language maintenance. Surprisingly, attitude and parents' role are similar in percentage. It means that 
attitude and parents' role have a big contribution in order to maintain the vernacular language at home domain.

\subsection{The Ways in Maintaining Vernacular Language}

\subsubsection{Language choice at home}

Language choice at home influences children's language. Children learn to speak and read in Batak Toba language at least at family domain. All parents speak Batak Toba language to their children at home by applying code-mixing between Indonesian and Batak Toba language. It makes children adopt Batak Toba language and they are able to speak Batak Toba language fluently.

\section{Data 1}

Interviewer : Biasanya pakai bahasa apa di rumah? (What kind of language do you speak at home?

Parent : Bahasa Batak sama bahasa Indonesia (Batak language and Indonesian)

\subsubsection{Bringing Children to Ethnic Church}

Learning a language is done by parents through religion; joining ethnic church, reading holy bible in Batak Toba language, and singing songs in Batak Toba language. It is done by two families.

\section{Data 2}

Interviewer: selain itu ada hal lain? (is there any factor?)

Parent: apa ya, gereja kali ya, kan di sana pakai bahasa batak. (what, maybe church, we speak Batak Toba language there).

\subsubsection{Hearing Traditional Songs}

Parents play Batak Toba songs at home and bring their children to Café or restaurant playing Batak Toba Songs. By hearing Batak's songs, children motivate to understand and know Batak Toba language.

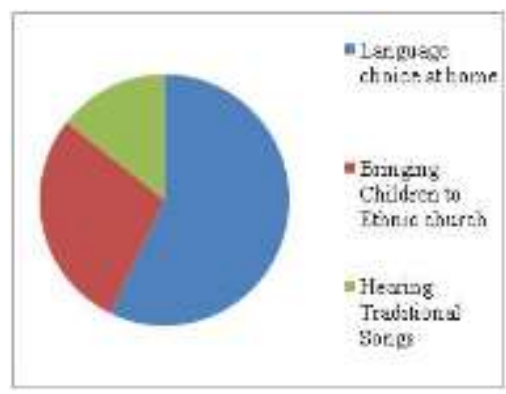

Fig. 2. The ways in maintaining vernacular language in inter-ethnic families.

Figure 2 represents language choice at home gave a big contribution in maintaining vernacular language than bringing children to ethnic church and hearing traditional songs.

\section{Discussion}


Inter-ethnic families maintain at least one vernacular language. Language is maintained if the generation of the speakers are able to speak their language. In this study, families maintain Batak Toba language in Medan. Medan is dominated by Malay tribe. In fact, Batak language dominates in Medan. It means the future generations from Javanese and Batak Toba families are able to speak Batak Toba language and it is supported by people in their region.

In this study, there are three factors influencing vernacular language maintenance in inter-ethnic families; Attitude, Parents' role at home and religion. The dominant factors are parent's role at home and Attitude. Preserving heritage language is important in this globalization era. It will keep the heritage language alive and save the ethnic's identity (Holmes, 2013). In inter-ethnic families; at least 2 languages at home, preserving is necessary. Practicing native language is embedded with family communication. Parents' positive attitude motivates their children to speak vernacular language (Sitinjak, 2013). Attitude motivates not only speakers to speak Batak Toba language to their children but also Children to others people. Parents as the leader in the family have power to choose Batak Toba language to be used at home. While, integrative motivation, view of importance of learning the language, and belief about parental attitudes toward learning the ancestral language influenced vernacular language maintenance in bilingual group and the most dominant factor is integrative motivation. This motivation contributed to others factors (Wharry, 1993). Family's effort stimulates and provides children to build a balanced bilingualism (Cohen, 2000).

There are three ways to maintain vernacular language in inter-ethnic families; language choice at home, bringing children to ethnic church, and hearing traditional songs. Language choice at home forces family members to speak the Batak Toba language. To support language choice, parents bring their children to ethnic church where the whole services are done in Batak Toba language. Joining ethnic church forces children to be able to speak Batak language (Sitinjak, 2013). Listening to Batak Toba's stimulates speakers' motivations to know, understand and speak Batak Toba language. Language maintenance can be done through promotion, encouraging speakers' awareness and establishing speakers' belief (Tulloch, 2006).

It is seen that inter-ethnic families; Javanese- Batak Toba are dominated by Batak Toba language. it is caused by Batak Toba culture. A man who gets married to Batak Toba woman is given one of Batak Toba surnames, automatically he becomes part of Batak Toba. This surname forces him to understand Batak Toba culture and be able to speak Batak Toba language. Father's positive attitude maintains his wife's language (Sitinjak, 2013).

\section{Conclusions}

The conclusions are 1) attitude and parents' role at home are the dominant factor in language maintenance and they are followed by religion. Attitude and parents' role at home force children to acquire and speak Batak Toba language automatically and continually. While Religion factor does not force children to speak Batak Toba continually. 2) Language choice at home, bringing children to ethnic church and hearing traditional songs are the ways to maintain Batak Toba language. Choosing Batak Toba language at home keeps the language alive by speaking Batak Toba language in communication with family members. Then, bringing children to ethnic church introduces Batak Toba language to Children. The last but not least, hearing traditional songs especially Batak Toba songs to children improve children's interest in Batak Toba language. 
This study suggest that vernacular language can be planned to be an extra subject in its region ,to support local television used vernacular language and to promote and to preserve traditional culture from every tribe.

\section{Acknowledgement}

First and foremost, praises and thanks to Jesus Christ for His blessing throughout in completing this manuscript. We would like to show our gratitude to the WMA Medan for comments that greatly improved this manuscript although any errors are our own.

\section{References}

[1] Cohen, M. (2000). Bilingual by Chance or by Choice: Language Maintenace and Loss in Simultaneous and Successive Bilinguals. Psycholinguistics on the Threshold of the year.

[2] Hoffmann, C. (1996). An introduction to bilingualism. London;New York : Longman. Retrieved from http://www.worldcat.org/title/introduction-tobilingualism/oclc/647494768

[3] Holmes, J. (2013). An Introduction to Sociolinguistics (Fourth Edi).

[4] Kim, G. (1995). Korean Diaspora in Kazakhstan: Question of Topical Problems for Minorities in Post-Soviet Space, 63-74.

[5] Miles, M. B., \& Huberman, M. (n.d.). Qualitative Data Analysis.

[6] Pauwels, A. (2005). Maintaining the Community Language in Australia: Challenges and Roles for Families. International Journal of Bilingual Education and Bilingualism, 8(2-3), 124-131. https://doi.org/10.1080/13670050508668601

[7] Sitinjak, V. N. (2013). LANGUAGE MAINTENANCE IN INTER-ETHNIC COUPLES. Retrieved from http://digilib.unimed.ac.id/4012/

[8] Tulloch, S. (2006). Preserving Dialects of an Endangered Language. Current Issues in Language Planning, 7(2-3), 269-286. https://doi.org/10.2167/cilp098.0

[9] Weinreich, U. (1979). Language in Contact: Findings and Problems. Mouton Publisher.

[10] Wharry, C. (1993). Bilingualism (Ancestral Language Maintenance) among Native American, Vietnamese American, and Hispanic American College Students. Bilingual Research Journal, 17. 